DOI 10.37882/2223-2982.2021.08.40 \title{
КРИТЕРИИ КЛАССИФИКАЦИИ ТОПОНИМОВ РОССИИ И КИТАЯ НА ПРИМЕРЕ НАЗВАНИЯ ГЕОГРАФИЧЕСКИХ ОБЪЕКТОВ
}

\section{CRITERIA FOR THE CLASSIFICATION OF TOPONYMS IN CHINESE AND RUSSIAN ON THE EXAMPLE OF THE NAME OF GEOGRAPHICAL OBJECTS}

Shi Jialu

Summary: The relevance of considering the criteria for the classification of Chinese and Russian toponyms using the example of the names of geographical objects is due to the fact that such criteria are of great importance in the study of comparative, typological and comparative historical linguistics. The article discusses the approaches of modern scientists to the definition of toponyms. The classification of Chinese and Russian toponyms, reflecting the names of geographical objects, is carried out from the perspective of lexical and semantic analysis. The general and distinctive features of toponymic units in comparable languages are highlighted.

Keywords: toponymy, classification, classification criteria, Chinese toponyms, Russian toponyms, toponymic units.

\author{
Ши Цзялу \\ Аспирант, Российский университет дружбы народов \\ 1964226971@qq.com
}

Аннотация: Актуальность рассмотрения критериев классификации китайских и русских топонимов на примере названия географических объектов обусловлена тем, что большое значение такие критерии имеют в исследовании сопоставительного, типологического и сравнительно-исторического языкознания. В статье рассматриваются подходы современных ученых к определению топонимов. Проводится классификация китайских и российских топонимов, отражающих названия географических объектов с позиции лексико-семантического анализа. Выделены общие и отличительные особенности топонимических единиц в сопоставимых языках.

Ключевые слова: топонимика, классификация, критерии классификации, китайские топонимы, русские топонимы, топонимические единицы.

При рассмотрении топонимов Китая и России, можно обнаружить достаточную распространенность топонимических единиц, обозначающих названия географических объектов, которые соотносятся с военной деятельностью.

При рассмотрении российских топонимов можно привести следующие примеры названия географических объектов, представленных в данной группе топонимических единиц:

- Кутузовский проспект и т.д.

Что же касается китайских топонимических единиц, то в их перечне так же можно встретить достаточное количество топонимов, которые связаны с военными событиями и являются географическими объектами. Например:

— 中山 [Чжуншань] - «городской округ Чжуншань в провинции Гуандун», назван в честь китайского революционера Сунь Чжуншань;

- 黄骅 [Хуанхуа] - «город Хуанхуа в провинции Хэбэй», назван в честь погибшего на войне с Японией Хуан Хуа;

- 获嘉 [Хоцзя] - «уезд Хоцзя в провинции Хэнань» и т.д. $[3$, с. $283 ; 7$, с. 35].

Следует при этом подчеркнуть тот факт, что в россий- 
ской топонимике такая лексико-семантическая группа топонимов представлена менее обширно, чем в китайской топонимике.

2. Топонимические единицы, которые связаны с описанием окружающей среды или природных географических объектов.

В содержательной структуре топонимических единиц, как следует подчеркнуть, отражаются характеристики соответствующих объектов географического характера, условия жизни национального народа и прочие характеристики. Выделенные обстоятельства отражаются и на лексико-семантической группе топонимов.

Множество географических объектов находятся на территории Китайской Народной Республики и России. Среди китайских топонимических единиц, обозначающих название географических объектов, по критерию описания окружающей среды или природных объектов могут быть выделены следующие основные группы:

1. Описательные топонимические единицы, которые классифицируют соответствующий географический объект:

а) ассоциации зрительного характера:

一 葫芦岛 [Хулудао] - «острова в форме тыквы горлянки».

б) основные особенности рельефа:

- 平顶山 [Пиндиншань] - «гора сплоской вершиной».

в) ассоциации ольфакторного характера:

一 香港 [Гонконг] - «пахучая гавань».

г) сочетание родового термина с компонентов цветового характера:

— 河 [Хуанхэ] - «желтая река».

2. Локализация географического объекта по его местоположению:

а) топонимические единицы, в которых местоположение соответствующих географических объектов указывается относительно друг друга:

— 河南 [Хэнань] - «провинция находится на юге реки»;

— 湖南 [Хунань] - «провинция к югу от озера»;

- 上海 [Шанхай] - «город на море».

б) топонимические единицы, включающие в себя компонент中 [чжун] - «центральный»:

- 中岳 [Чжунъюэ] - «центральная гора»;

- 晋中 [Цзиньчжун] - «центральная Шаньси».

в) топонимические единицы, указывающие на географические объекты по сторонам света:

- 北京 [Пекин] - «северная столица»;

— 河南 [Хэнань] - «к югу от реки Хуанхэ»;

- 台北 [Тайбэй] - «город на севере Тайваня».

- указание местоположения географических объектов относительно друг друга: 上海 [Шанхай] «на море»; провинция湖南 [Хунань] - «провинция к югу от озера», расположена на юге озера洞庭湖 [Дунтинху]; 河南 [Хэнань] «провинция на юге реки» расположена на юге реки Хуанхэ.

В России топонимические единицы, объединенные в группу выделенного критерия, довольно часто образуются по наименованию природного объекта в районе географического объекта:

1. наличие гор:

- Магнитогорск;

- Пятигорск;

- Солнечногорск и т.д.

2. наличие рек, озер и морей:

- Азов;

- Волгоград;

- Амурск;

- Байкал;

- Томск и т.д.

3. другие природные объекты:

- Болотное;

- Бор и т.д.

3. Топонимические единицы, которые связаны с национальной символикой или религией. В сопоставимых государствах, как следует подчеркнуть, имеются собственные понятия религиозного характера. Такие понятия находят непосредственное отражение в топонимах России и Китая.

В Китайской Народной Республики присутствуют определенные традиции религиозного характера, которые способствовали формированию определенных топонимических единиц:

- 仙游县 [уезд Сянью] - «уезд, где путешествуют Боги»;

— 天山 [Тянь-Шань] - «божественные горы»;

— 佛山 [Фошань] - «гора Будды» и т.д.

В России топонимические единицы, связанные с национальной религией и символикой, раскрывают основные понятия христианской религии:

- Воскресенск;

- Архангельск;

- Великие Луки;

- Богородицк и т.д.

4. Топонимические единицы, характеризующие названия географических объектов, связанных с ресурсами минерального характера.

Как Китай, так и Россия обладают достаточно богатым числом месторождений и запасов природных ресурсов. В результате наличия таких минеральных месторождений формировались соответствующие названия географических объектов.

Среди китайских топонимов, которые входят в такие критерии классификации топонимов, можно выделить: 
— 铜陵 [Тунлин] - «медные горы»;

一 白银市 [город Байинь] - «город серебра» и т.д.

В свою очередь, в российской топонимике так же встречается достаточно большое количество названий географических объектов, топонимическая структура которых обусловлена исследуемым критерием:

- Соликамск;

- Магнитогорск;

- Нефтеюганск и т.д.

5. Топонимические единицы, имеющие в собственной структуре название антропонимов. Такие топонимы встречаются как в китайской, так и в российской топонимии.

В российской топонимике названия географических объектов, включающих антропонимы, в большинстве случаев включают в себя имена культурных и исторических деятелей. К примеру:

- Хабаровск;

- Екатеринбург;

- Пушкин и т.д.

Что же касается китайских топонимических единиц, то в данной стране довольно часто наблюдается два вида топонимов, входящих в исследуемую группу критериев:

1. топонимические единицы, которые названы по наиболее известной фамилии в конкретном географическом объекте:

- 田庄 [Тяньчжуан] - «деревня семьи Тянь».

2. топонимические единицы, которые в своем содержании имеют имена первых людей, проживающих на конкретной территории:

— 石家庄 [Шицзячжуан] - «деревня семьи Ши».

6. Топонимические единицы, которые соотносятся с названиями конкретных растений. Такие топонимы встречаются в сопоставимых языках и отражают преобладание конкретного вида растения на географическом объекте. В китайской топонимике встречаются следующие виды топонимов из данной категории критериев:

— 柳林 [Люлинь] - «ивовый лес»;

- 桃园 [Таоюань] - «персиковый сад» и т.д.

Среди российских топонимов, которые входят в такую группу критериев, прежде всего, можно отнести:

- Дубна (дуб);

- Липецк (липа);

- Дубовка (дуб);

- Черемхово (черемуха);

- Ельня (ель) и т.д.

7. Топонимические единицы, которые номинируют географические национальные объекты по хозяйствен- ным и экономическим факторам. Экономическое развитие государств так же оказывает существенное влияние на формирование топонимов, обозначающих название географических объектов. В данном случае можно привести следующие вариации китайских топонимических единиц:

— 鱼市 [Юй Ши] - «рыбный рынок»;

一 羊庄 [Ян Чжуан] - «село овечье» и т.д.

Среди российских топонимов в данной категории критериев могут быть выделены следующие топонимические единицы:

- Рыбкин (рыбный промысел);

- Ковров (ткацкий промысел);

- Кузнецк (кузнецкое дело);

- Торжок (торг) и т.д.

8. Топонимические единицы, которые связаны с названием животных. Такие топонимы, обозначающие названия географических объектов, встречаются в России и Китае довольно часто. Приведем несколько примеров.

В китайском языке:

- 飞龙 [Фэйлун] - «летающий дракон»;

- 宝鸡 [Баоцзи] - «драгоценная курица» и т.д.

В русском языке можно привести следующие примеры исследуемой группы топонимов:

- Лосево;

- Орел;

- Козловка;

- Лебедянь и т.д.

В китайской топонимике так же существуют некоторые топонимы, обозначающие названия географических объектов, которые не представлены в русской топонимике. Эта группа критериев может быть обозначена, как - мифологические топонимы. В структуру мифологических топонимов входят две группы топонимов:

1) топонимические единицы, которые описывают мифологические события:

— 燕山 [Яньшань] - «гора ласточкина», прилет ласточек по приданию совпадает с ритуалами плодородия весной.

2) топонимические единицы, которые связаны с китайским гороскопом:

— 狗街 [Гоуцзе] - «проспект собаки»;

— 鸡街 [Цзицзе] - «проспект петуха» и т.д. [5, с. 76].

Проведенное сравнительное исследование свидетельствует о том, что и в китайской, и в русской топонимике при описании названий географических объектов можно выделить достаточно большое количество 
критериев. При этом, практически все рассмотренные в рамках настоящей статьи критерии встречаются в исследуемых языках.

Отличительной особенностью российских топонимических единиц, характеризующих названия географических объектов, считается более обширное количество названий географических объектов, которые были названы в честь известного деятеля.

В китайской топонимике так же присутствуют отличительные особенности. Так, уникальными топоними- ческими единицами, обозначающими географические объекты Китая, являются мифологические топонимы. В структуру мифологических китайских топонимов входят топонимы, которые описывающие мифологические события, и топонимы, связанные с китайским гороскопом.

Таким образом, названия географических объектов в Китае и России отражают основные события, которые происходили в сопоставимых языках, в частности: в социальной, духовной сфере, в сфере искусства и культуры, в области экономико-политических отношений.

\section{ЛИТЕРАТУРА}

1. Лю Лу. Способы и мотивы наименования географических объектов в китайском и русском языках // Litera. 2021. № 5. С. 97-105.

2. Нимгирова М.А. К вопросу об изучении топонимики // Rhema. Рема. 2011. №4. С. 71-75.

3. Ню Жучэнь. Китайская культурная топонимика. Китайское научно-техническое издательство, 2018. - 755 с.

4. Фаткуллина Ф.Г. Топонимическая лексика как отражение национальной языковой картины мира // European Social Science Journal (Европейский журнал социальных наук). 2014. № 3. Т. 1. С. 212-225.

5. Ши Цзялу. Критерии классификации географических названий Китая и России // Litera. 2019. № 6. C. 66-77.

6. Ши Цзялу. Сравнительный анализ топонимов в русском и китайском языках в аспекте лексико-семантических особенностей номинации // ФилологичеСкие науки. Вопросы теории и практики. 2021. № 6. С. 1934-1937.

7. Языкова А.А. Функционально-семантическая характеристика китайских топонимов // Вестник БГУ. Язык, литература, культура. 2018. № 1. С. 31-36.

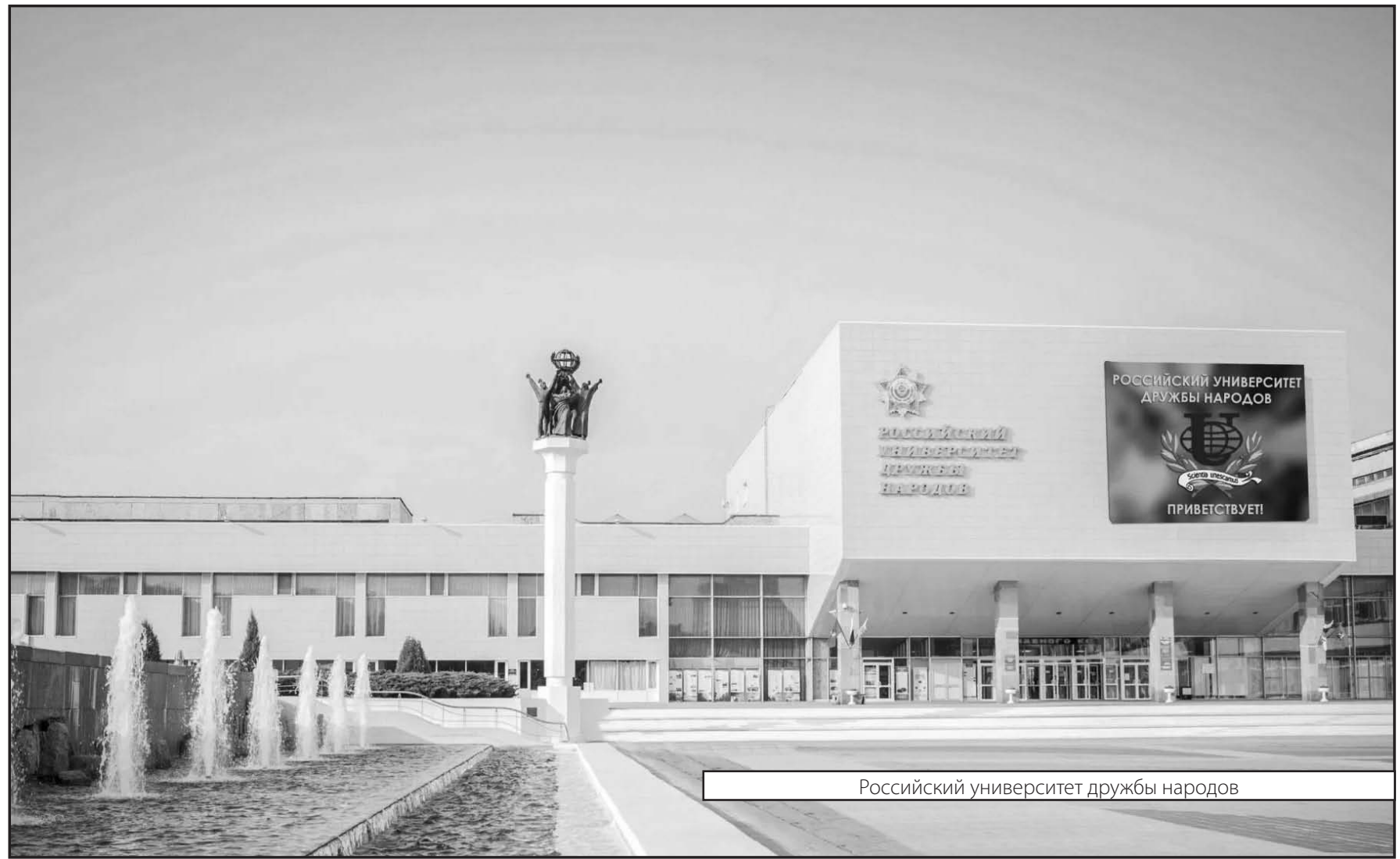

